\title{
THE RELATIONSHIP BETWEEN POST-PURCHASE BRAND AWARENESS AND CONSUMER BEHAVIOR AMONG SOCIAL MEDIA USERS
}

\section{SOSYAL MEDYA KULLANICILARI AÇISINDAN SATIN ALMA SONRASI MARKA FARKINDALIĞI VE TÜKETİII DAVRANIŞLARI ARASINDAKİ İLIŞSI*}

\author{
Selahattin SÖYLEMEZ1 | Adnan DUYGUN2,** \\ 1 İstanbul Gelişim Üniversitesi, Sosyal Bilimler Enstitüsü, İşletme Yüksek Lisans Mezunu, İstanbul, Türkiye, s.soylemez90@gmail.com, \\ ORCID: 0000-0001-8698-9312 \\ 2 Dr. Öğr. Üyesi, İşletme (İngilizce) Bölümü, İktisadi İdari ve Sosyal Bilimler Fakültesi, İstanbul Gelişim Üniversitesi, İstanbul, Türkiye, \\ aduygun@gelisim.edu.tr, ORCID: 0000-0003-4026-4054
}

\section{Article Info: \\ Received : May 8, 2020 \\ Revised : May 28, 2020 \\ Accepted : June 9, 2020 \\ Keywords: \\ Brand Awareness \\ Consumer Behavior \\ Social Media \\ Anahtar Kelimeler: \\ Marka Farkındalı̆ğ \\ Tüketici Davranışı \\ Sosyal Medya}

DOI: $10.46238 /$ jobda. 734260

\begin{abstract}
In the rapidly developing marketing field, the importance of providing brand awareness, image and trust under the increasing competition conditions of brands, is increasing on daily basis. By branding their products, companies gain a competitive advantage in the markets and their chances of survival under increasing competition conditions increase. Brand awareness therefore has been gaining importance for the brand research. Another issue that needs attention and attention is the buying behavior of consumers. Considering that the usage of internet and social media has increased rapidly in recent years, it is possible to say that social media is effective on consumer buying behavior. The aim of this study; is to examine the social media dimension of the relationship of consumers after purchase by explaining the importance of brand awareness. The study has been done in Istanbul and a questionnaire was conducted on 400 social media user. When the data obtained from the survey were examined, he results indicated that there was a positive significant relationship between post-purchase brand awareness and social media user behavior after purchase.

\section{ÖZET}

Hızla gelișen pazarlama alanında, markaların artan rekabet koșulları altında; marka farkındalığı, imaj ve güven sağlamanın önemi her gün artmaktadır. $\mathrm{Bu}$ sayede işletmeler, pazarda rekabet avantajı elde edebilmekte ve hayatta kalabilme şanslarını artırabilmektedirler. Marka çalışmalarında öne çıkan kavramlardan birisi ise marka fakındalığıdır. Üzerinde durulması ve dikkat edilmesi gereken bir diğer konu ise tüketicilerin satın alma davranışıdır. Son dönemlerden internet ve buna bağlı olarak da sosyal medya kullanımının hızla arttığı düşünüldüğünde, tüketici satın alma davranışı üzerinde sosyal medyanın etkili olduğunu söylemek mümkündür. $\mathrm{Bu}$ çalışmanın temel amacı, satın alma sonrasında marka farkındalığı ve tüketici davranışı arasındaki ilişkinin, sosyal medya kullanıcıları açısından incelenmesidir. Araştırma İstanbul'da gerçekleștirilmiş ve 400 sosyal medya kullanıcısına anket uygulanmıştır. Anketten elde edilen veriler incelendiğinde satın alma sonrası marka farkındalığı ile satın alma sonrası sosyal medya kullanıcılarının davranışları arasında pozitif yönde anlamlı bir ilişki olduğu ortaya çıkmıştır.
\end{abstract}

(C) 2020 JOBDA All rights reserved

\footnotetext{
* Bu çalışma, Dr. Öğr. Üyesi Adnan Duygun danışmanlığında Selahattin Söylemez tarafından hazırlanan “Satın Alma Sonrası Marka Farkındalığı ve Tüketici Davranışları Arasındaki İlişkinin İncelenmesi: Sosyal Medya Kullanıcıları Üzerine Bir Çalışma” başlıklı yüksek lisans tezinden üretilmiştir.

${ }^{* *}$ Corresponding Author, E-mail: aduygun@gelisim.edu.tr (A. Duygun)
} 


\section{1 | GíRIş}

Son dönemlerde işletmelerin gündemindeki yerini kaybetmeyen çalışma alanlarından birinin, ürettikleri ürün ve hizmetlere ait markaları geliştirmek olduğunu söylemek mümkündür. Marka çalışmalarına bağlı olarak tüketici nezdinde marka farkındalığının yaratılması ise pek çok ișletme açısından önemli gündem konusu olmaya devam etmektedir.

İşletmelerin temel amaçlarından birisi ürün ve hizmetlerini satarak kar elde etmektir. İnternetin ve buna bağlı olarak sosyal medyanın hızla geliştiği ve kullanıcı sayısının sürekli arttığı bir ortamda, işletmeler ürün ve hizmetlerini satmak ve sattıktan sonra da tüketicilerden geri bildirim almak için interneti ve özellikle de sosyal medyayı yoğun bir şekilde kullanmaktadırlar.

Dolayısıyla, işletme ile tüketiciler arasında ilişki kurmak için en yaygın kullanılan araçlardan birinin sosyal medya olduğunu ifade etmek mümkündür (Duygun, 2020, s. 61). Tüketicilerin sosyal medya ortamında yaptıkları olumlu ya da olumsuz yorumlar marka algısı oluşturmakta ve bu yorumlar tüketicilerin satın alma kararlarını etkilemektedir (Toksarı vd., 2014, s. 3).

Buraya kadar bahsedilen hususları göz önüne alarak yapılan bu çalışmadaki temel amaç, satın alma sonrasında marka farkındalığı ve tüketici davranışı arasındaki ilişkinin, sosyal medya kullanıcıları açısından incelenmesidir.

Çalışmada öncelikle marka ve marka farkındalığı kavramlarına yer verilmiştir. Ardından sırasıyla; tüketici davranışı ve tüketici davranışlarını etkileyen faktörlere, sosyal medya ve tüketici davranışlarına ve araştırmanın metodolojisine değinilmiştir. En son olarak da araştırmada elde edilen sonuçlar irdelenmiş ve konuyla ilgilenebilecek olan akademisyen ve araştırmacılara önerilerde bulunulmuştur.

\section{2 | MARKA VE MARKA FARKINDALIĞI}

Amerikan Pazarlama Birliği'nin (AMA) tanımına göre marka "bir ürün ya da bir grup satıcının ürünlerini ya da hizmetlerini belirlemeye, tanımlamaya ve rakiplerin ürünlerinden ya da hizmetlerinden farklılaştırmaya, ayırt etmeye yarayan isim, terim, işaret, sembol, tasarım, şekil ya da tüm bunların bileşimidir" (Odabaşı ve Oyman, 2003, s. 360).

Bir işletmenin en önemli parçalarından biri olan marka, benzer ürün veya hizmet sağlayan işletmelerden, markanın ayırt edilmesini ve fark edilmesini sağlarken, markanın taklit edilmesini de zor hale getirmektedir (Ar, 2004, s. 7).

Marka, satın alma sürecinde, tüketicinin ürün veya hizmet hakkında bilgi edinmesini sağlayan önemli bir iletişim aracı rolünü üstlenmektedir. Bunun yanı sıra marka, müșterinin beklenti ve istekleri doğrultusunda, hizmet veya ürünlere ulaşma imkânı sağlamakta ve tüketicinin satın alma sürecinde katkı sağlamaktadır (Aktuğlu ve Temel, 2006, s. 43).

Marka farkındalığı ise "markanın tanınması, pazarda veya reklamda tüketici tarafından görülmesi ve tüketicinin markayı gördüğünün farkında olması" şeklinde tanımlanabilmektedir. Tüketici markanın farkında değilse markayı ya bilmiyordur ya da görmüş olsa bile fark edememiştir (Cop ve Baş, 2010, S. 322).

Bir markadan akılda kalmış olanlar hafızanın bir tarafında toplanmış olmaktan ziyade, birçok bölgeye dağılmıştır. Marka anımsanırken tüketicilerin aklına gelmekte olan ilk şey durumlara ve ip uçlarına dayanmaktadır. Bu ip uçlarının tüketiciye sunulma biçimi ve diğer öğelerle olan arasındaki ilişkinin bellekte oluşan gücü, bir şeyin hatırlanıp hatırlanmamasını ve neyin hatırlandığını göstermektedir. Marka ile karşılaşma ne kadar kısa süre önce meydana gelmiş ise, bu karşılaşmanın, kişinin bilincine tekrar dönebilme ve yeni oluşacak bilginin işleme geçme olasılığı da o kadar yüksek olacaktır (Cop ve Baș, 2010, s. 323).

Markanın taşımakta olduğu önem göz önüne alındığında, işletmeler açısından marka farkındalığı oluşturmanın, birincil amaç olması gerektiğini söylemek mümkündür. Çünkü farkındalık, tüketicinin satın alma karar sürecini ve marka değerini direkt olarak etkileyebilmektedir. Tüketiciler bir ürün satın alacakları zaman alacakları ürünün ve markanın farkında olmalıdırlar. Marka tüketicide farkındalık oluşturmamış ise tüketici, o markanın ürün veya hizmetini tercih etmemekte ve satın almayı düşünmemektedir (Hacıoğlu Deniz, 2011, s. 258).

İşletmeler, markalarının farkında olan tüketicileri göz ardı etmemelidirler. Artan rekabet ortamı içinde yapılacak olan bir yanlış, tüketicinin algı ve dikkatini dağıtıp, tüketicinin marka farkındalığını düşürebilmektedir. Dolayısıyla, işletmelerin marka farkındalığı yaratırken, stratejilerini hedef pazarlara göre yapmaları, geliştirmeleri ve korumaları gerekmektedir (Aktepe ve Baş, 2008, s. 84). 
Şekil 1. Farkındalık Piramidi

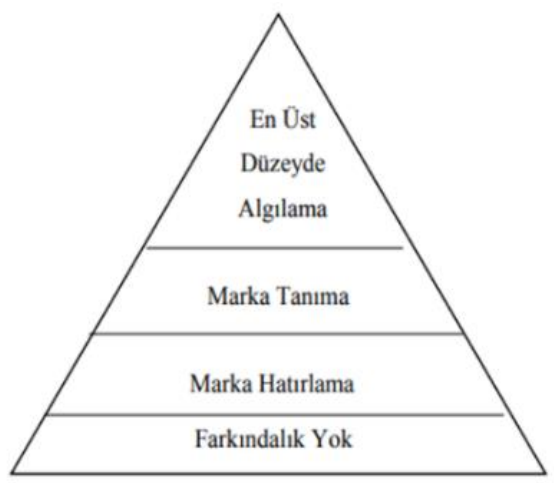

Kaynak: Pira vd., (2005, s. 89).

Şekil 1'de görülebileceği gibi tüketiciler bazında marka fakındalığının dört farklı düzeyde olduğunu ifade etmek mümkündür. İlk basamakta tüketicilerin marka hakkında farkındalıkları oluşmamış durumdadır. İkinci basamakta tüketicilerin markayı hatırladıkları, üçüncü basamakta ise markayı tanıdıkları görülmektedir. Son basamağa gelindiğinde ise tüketicilerin marka ile ilgili en üst düzeyde algılama seviyesinde oldukları ortaya konmaktadır.

Ayrıca marka farkındalığı, marka değerini oluşturan boyutlardan birisidir. Marka değerini oluşturan boyutlar genel olarak; marka farkındalığı, marka çağrışımları ya da imajı, algılanan kalite ve marka bağlılığı ya da sadakati şeklinde sıralanmaktadır (Ural ve Perk, 2012, s. 13; Ayas, 2012, s. 167-169; Çetinsöz ve Artuğer, 2013, s. 201; Avcılar, 2008, s. 13).

\section{3 | TÜKETİCI DAVRANIŞI VE TÜKETICI DAVRANIŞLARINI ETKIILEYEN FAKTÖRLER}

Tüketici davranışı; hangi hizmet veya ürünün satın alınacağl, kimden, nasıl, nereden ve ne zaman satın alınacağı ve son olarak satın alınıp alınmayacağı ile ilgili tüketicilerin kararlarına ait bir süreçtir. İnsan davranışının bir alt bölümü olan tüketici davranışı, tüketicinin özellikle ekonomik ürünleri ve hizmetleri satın alma ve kullanmadaki kararları ve bununla ilgili faaliyetlerini içermektedir (Odabaşı, 1998, s. 8).

Tüketicilerin karar verme sisteminin nasıl çalıştığ net bir şekilde bilinmemektedir. Çünkü her insanın kendisine özgü olan bir davranış modeli bulunmaktadır. Karar verme anında birçok unsur devreye girmekte ve bu unsurların sayısı kişiden kişiye farklılık gösterebilmektedir. Bir süreç olarak tüketici davranışı, öncelikle bir insan davranışı olduğundan, insanı etkileyen her etken tüketicinin satın alma davranışını da etkileyebilmektedir (Bardakçı vd., 2015, s. 621).

Tüketici davranışlarını ve bu davranışların arkasındaki faktörleri ifade edebilmenin zorluğu, konunun karmaşık bir yapıda bulunmasından kaynaklanmaktadır. Bu davranışlar tüketicinin kişisel olarak ihtiyaçlarının, öğrenme sürecinin, güdülerinin, algılamalarının, kişiliğinin, tutum ve inançlarının etkisi; öte yandan da kişinin, yaşadığı toplumda sosyal sınıf, kültür ve aile gibi sosyo-kültürel faktörlerin etkisiyle ortaya çlkmaktadır. Bunun dışında, işletmelerin pazarlama faaliyetlerinin de tüketici davranışlarına etkisi olmaktadır (Mucuk, 2001, s. 285).

Genel olarak, tüketicinin satın alma kararlarını etkileyen dört temel faktör olduğunu söylemek mümkündür. Bunlar; kültürel, sosyal, psikolojik ve kişisel faktörlerdir (Durmaz vd., 2011, s. 118).

\section{4 | SOSYAL MEDYA VE TÜKETİCI DAVRANIŞLARI}

Öncelikle sosyal medya kavramına değinmekte yarar bulunmaktadır. Sosyal medyayı; kullanıcılar tarafından geliştirilen içeriğin oluşturulmasına ve değiştirilmesine olanak tanıyan bir grup internet tabanlı uygulama (Kaplan ve Haenlein, 2010, s. 61) olarak ifade etmek mümkündür.

Sonrasında ise literatürde marka farkındalığı ve marka ile sosyal medya kullanıcıları üzerine yapılmış örnek çalışmalara yer vermek yararlı olacaktır. Aşağıda yapılmış çalışmalardan örneklere yer verilerek, genel olarak çalışma ile ilgili bir literatür özeti ortaya konmuştur.

İşlek (2012, s. 2) 845 sosyal medya kullanıcısı ile gerçekleştirdiği çalışmasında, sosyal medyanın tüketici davranışlarına etkisini incelemiştir. Ortaya çıkan sonuca göre satın alma sürecinde tüketiciler sosyal medya araçlarından etkilenmektedirler.

Aytan ve Telci $(2014$, s. 1) yaptıkları çalışmaya 465 sosyal medya kullanıcısını dahil etmişler ve markaların sosyal medya kullanımlarının tüketici davranışı üzerindeki etkilerini araştırmışlardır. Elde edilen sonuca göre markaların sosyal medya kullanımının tüketici davranışları üzerinde etkili olduğu anlaşılmıştır.

Kazancı ve Başgöze (2015, s. 435) yaptıkları çalışma ile sosyal medya algısının, marka kredibilitesi ve prestijinin satın alma eğilimi üzerine etkilerini ortaya koymuşlardır. Araştırmaya 417 katılımcı dahil olmuştur. Sonuç olarak; sosyal medya algısının, marka kredibilitesi, marka prestiji ve satın alma eğilimini olumlu yönde etkilediği belirlenmiştir.

Hollebeek ve diğerleri (2014, s. 149) sosyal medyada tüketici marka etkileşimi üzerine bir ölçek geliştirme çalışması ortaya koymuşlardır. Ölçek üç boyut (bilişsel süreçten geçme, düşkünlük ve harekete geçme) ve on maddeden oluşmuştur.

Barreda ve diğerleri (2015, s. 600) çevrimiçi sosyal ağlarda marka farkındalığı oluşturmak üzerine çalışmışlardır. Çalışmaya 230 çevrimiçi sosyal ağ kullanıcısı dahil edilmiştir. Çalışma sonuçları, çevrimiçi sosyal ağlarda marka farkındalığı oluşturmanın ağızdan ağıza iletişim trafiğini 
arttırdığını ortaya koymuştur. Çevrimiçi sosyal ağlarda, marka farkındalığını arttırmak için kullanıcıların güvenilir, zengin ve güncel bilgileri zamanında paylaşmalarını sağlayan, etkileşimli bir ortam yaratmanın önemli olduğuna değinilmiştir.

Shojaee ve bin Azman (2013, s. 72) Malezya'da sosyal medya üzerinden marka farkındalığını etkileyen faktörleri değerlendirmişlerdir. Çalışmanın verileri Putra Malezya Üniversitesi'nin 391 öğrencisinden elde edilmiştir. Sonuçlar, müşteri etkileşimi, marka yayılımı ve elektronik ağızdan ağıza iletişimin sosyal medya bağlamında marka farkındalığı ile olumlu bir korelasyona sahip olduğunu ve en etkili faktörün müşteri etkileşimi olduğunu göstermiştir.

Bilgin (2018, s. 128) sosyal medya üzerinden yapılan pazarlama aktivitelerinin marka farkındalığına, marka imajına ve marka sadakatine olan etkisini incelemiştir. Çalışma sonucunda, sosyal medyaki pazarlama aktivitelerinin, marka imajı ve marka sadakati üzerinde etkili olduğu, en belirgin etkisinin marka farkındalığı üzerinde olduğu belirlenmiștir. Ayrıca marka farkındalığının ve marka imajının, marka sadakati üzerinde anlamlı bir etkiye sahip olduğu, marka farkındalığının ise marka imajı üzerinde sınırlı bir etkisinin olduğu tespit edilmiştir.

Momany ve Alshboul (2016, s. 33) yaptıkları çalışmanın amacını, sosyal medyanın marka farkındalığı ve çevrimiçi satışlar üzerindeki etkisini ölçmek olarak ifade etmişlerdir. Çalışmanın kapsamına; küçük otelleri dahil etmişlerdir. Çalışmanın sonuçları sosyal medyadaki sosyal yardım çabaları ile marka farkındalığı ve çevrimiçi satışlar arasında güçlü korelasyonlar olduğunu göstermiştir.

\section{5 | ARAŞTIRMANIN METODOLOJİSI}

Bu kısımda; araştırmanın amacı, araştırmanın önemi, araştırmanın sınırlılıkları, araştırmanın evreni ve örneklem büyüklüğü, veri toplama yöntemi ve araştırmanın değişkenleri ile araştırmanın modeli ve hipotezleri üzerinde durulmuştur.

\section{1 | Araştırmanın Amacı}

$\mathrm{Bu}$ araştırmadaki temel amaç; sosyal medya kullanıcılarının satın alma sonrası marka farkındalığı ve tüketici davranışları arasındaki ilişkinin incelenmesidir. Araştırmanın alt amaçları ise şu şekilde sıralanmaktadır:

- Tüketici olarak sosyal medya kullanıcılarının sosyo-demografik özelliklerini ortaya koymak,

- Satin alma sonrasinda sosyal medya kullanıcılarının marka farkındalığını belirlemek,

- Satin alma sonrasinda sosyal medya kullanıcılarının davranışını saptamak,

- Marka farkındalığı açısından sosyal medya kullanıcılarının sosyo-demografik özellikleri arasında fark olup olmadığını ortaya koymak,
- Tüketici davranıșı açısından sosyal medya kullanıcılarının sosyo-demografik özellikleri arasında fark olup olmadığını belirlemek.

\section{2 | Araştırmanın Önemi}

Bu çalışmada, sosyal medya kullanıcılarının aldıkları ürünler hakkındaki marka farkındalıklarına ve satın alma sonrası davranıșlarına yer verilmiștir. Ürün olarak akıllı telefonlar, marka olarak da akıllı telefon markaları seçilmiştir. Ayrıca sosyal medya kullanıcılarının, akıllı telefon kullanma davranışları ile sosyal medya kullanma davranışları üzerinde durulmuştur. Markaların hemen hepsinin sosyal medyada yer aldığı hesaba katıldığında, bahsedilen konuların pazarlama ve marka yöneticilerine fikir vermesi ve yol göstermesi açısından bu çalışmanın önem taşıdığını söylemek mümkündür.

\section{3 | Araştırmanın Sınırlılıkları}

İstanbul ili ile sınırlandırılan çalışmada akıllı telefona sahip sosyal medya kullanıcılarına akademik amaçlar için faydalanılacağı ve bunların hiçbir kişi ve/veya kuruluşa verilmeyeceği konusunda bilgi verilmiştir.

$\mathrm{Bu}$ sebeple akıllı telefona sahip sosyal medya kullanıcılarının anket ölçeğindeki ifadeleri doğru algılayıp, samimi bir şekilde cevapladıkları varsayılmaktadır. İnsan unsurunun temelinde bulunduğu bu çalışmada da sosyal bilimlerdeki araştırmalara özgü genel sinırlılıklar geçerli olup, toplanan analiz ve sayısal verilerin güvenilirliği, veri toplama yönteminde kullanılan anket tekniğinin özellikleriyle sınırlıdır.

\section{4 | Araştırmanın Evreni ve Örneklem Büyüklüğü}

Araştırmanın evreni, akıllı telefon kullanan ve sosyal medya ağlarından en az birine üye olan sosyal medya kullanıcılarından oluşmaktadır. Ancak zaman ve maliyet açısından herkese ulaşmak mümkün olmadığından, araştırma İstanbul'daki akıllı telefon kullanan sosyal medya kullanıcıları ile gerçekleştirilmiştir. Buna rağmen araştırma kapsamına dahil olan pek çok kişi olduğundan, örnekleme yapılmış ve yöntem olarak ise tesadüfi olmayan örnekleme yöntemlerinden kolayda örnekleme yöntemi kullanılarak, 400 akıllı telefon kullanan sosyal medya kullanıcısı ile anket çalışması gerçekleştirilmiştir.

\section{5 | Veri Toplama Yöntemi ve Araştırmanın Değişkenleri}

Veri toplama yöntemi olarak anket kullanılan çalışmada, konuyla ilgili ölçeklerden oluşan anket formu hazırlanmış ve uygulanmıştır. Anket formunda akıllı telefon kullanan sosyal medya kullanıcılarının belirlenmesi amacıyla, "Akıllı telefon kullanıyor musunuz?" ve "En az 1 sosyal medya hesabı kullaniyor musunuz?" şeklinde iki filtre sorusu 
sorulmuş ve bu sorulara evet cevabı veren sosyal medya kullanıcıları ile ankete devam edilmiştir.

Kullanılan anket 3 ana bölümden oluşmaktadır. Anketin ilk bölümünde sosyal medya kullanıcılarının sosyo-demografik özelliklerinin belirlenmesine, akıllı telefon kullanma davranışlarına ve sosyal medya kullanma davranışlarına ilişkin sorular bulunmaktadır. İkinci bölümde, satın alma sonrası marka farkındalığını ölçmeye yönelik ifadeler yer almaktadır ve Aysel Erciş, Şükrü Yapraklı ve Polat Can (2015, s. 168) tarafından yapılan çalışmadan yararlanılmıștır. Son bölüm ise, satın alma sonrası sosyal medya kullanıcılarının davranışlarını irdeleyen ifadelerden oluşmaktadır ve İşlek (2012, s. 166) tarafından yapılan çalışmadan faydalanılmıştır. Marka farkındalığı ölçeği 14 sorudan, satın alma sonrası sosyal medya kullanıcı davranışı ölçeği ise 9 sorudan oluşmaktadır.

Araştırmada kullanılan değişkenler şu şekilde siralanmaktadır:

- Sosyo-demografik özellikler:

o Cinsiyet

○ Yaş

- Medeni durum

- Eğitim durumu

- Gelir durumu

- Akıllı telefon kullanma davranışları

- Kullanılan akıllı telefon markası

- Akıllı telefon değiștirme sıklığı

- Sosyal medya kullanma davranışları

- En çok kullanılan sosyal medya ağı

- Sosyal medyada günde harcanan zaman

- En çok hangi amaçla sosyal medya kullanıldığı

- Satın alma sonrası marka farkındalığına ilişkin değişkenler:

- MF1-Kullandığım akıllı telefon markasının görünüşünün/şeklinin nasıl olduğunu bilirim.

- MF2-Kullandığım akıllı telefon markasını diğer akıllı telefon markaları arasında tanırım.

- MF3-Kullandığım akıllı telefon markasının farkındayım.

○ MF4-Kullandığım akıllı telefon markasının bazı özellikleri çabucak aklıma gelir. (Ekran boyutu, kamera, dahili hafıza vs.)

- MF5-Kullandığım akıllı telefon markasının sembol veya logosunu kolayca hatırlarım.

○ MF6-Kullandığım akıllı telefon markasını aklımda hayal etmem zordur.

- MF7-Kullandığım akıllı telefon markası, akıllı telefonlar arasında bilinen bir markadır.

○ MF8-Kullandığım akıllı telefon markası ürünlerini çok iyi tanıtıyor.
○ MF9-Kullandığım akıllı telefon markasının reklam/tanıtımlarından haberdarım.

○ MF10-Kullandığım akıllı telefon markasının herkes tarafindan bilindiğini düşünüyorum.

○ MF11-Kullandığım akıllı telefon markası, akıllı telefon markaları arasında aklıma ilk gelen isimdir.

○ MF12-Kullandığım akıllı telefon markasını satın almadan önce üreticisi hakkında bilgim vardı.

o MF13-Kullandığım akıllı telefon markasını satın almadan önce markanın akıllı telefonları hakkında bilgim vardı.

○ MF14-Kullandığım akıllı telefon markası hakkında olumlu fikirlere/düşüncelere sahibim.

- Satın alma sonrası sosyal medya kullanıcı davranışlarına ilişkin değişkenler:

○ KD1-Satın aldığım akıllı telefondan memnun kalırsam bunu sosyal medyada paylaşırım.

○ KD2-Satın aldığım akıllı telefondan memnun kalırsam bunu sosyal medyadaki şirket sayfalarında paylaşırım.

- KD3-Satın aldığım akıllı telefondan memnun kalmazsam bunu sosyal medyada paylaşırım.

○ KD4-Satın aldığım akıllı telefondan memnun kalmazsam bunu sosyal medyadaki şirket sayfalarında paylaşırım.

o KD5-Satın aldığım akıllı telefondan memnun kalırsam sosyal medyada diğer kullanıcılara o akıllı telefonu almalarını tavsiye ederim.

○ KD6-Satın aldığım akıllı telefondan memnun kalmazsam sosyal medyada diğer kullanıcılara o akıllı telefonu almamalarını tavsiye ederim.

- KD7-Satın aldıktan sonra memnun olduğum akıllı telefon markasının sosyal medyada beni fark ederek, benimle iletişime geçmiş olması memnuniyetimi daha da arttırır.

- KD8-Satın aldıktan sonra memnun olmadığım akıllı telefon markasının sosyal medyada beni fark ederek, benimle iletişime geçmesi fikrimi değiştirerek memnun olmamı sağlayabilir.

- KD9-Satın aldıktan sonra memnun olmadığım akıllı telefon markasının sosyal medyada beni fark etmeyerek, benimle iletişime geçmemesi memnuniyetsizliğimi arttırir. 
Anket formunda yer alan satın alma sonrası marka farkındalığı ölçeğindeki MF6 (Kullandığım akıllı telefon markasını aklımda hayal etmem zordur) değişkeni, olumsuz yargı olarak sorulmuştur. Anket çalışması tamamlandıktan sonra, bu değişken ile ilgili gerekli dönüşümler yapılarak olumlu hale getirilmiş ve sonrasında analize dahil edilmiştir.

\section{6 | Araştırmanın Modeli ve Hipotezleri}

Araştırmanın değişkenlerine göre ortaya konan araştırma modeli Şekil 2'de görülmektedir. Modelde; sosyal medya kullanıcılarının sosyo-demografik özellikleri, sosyal medya kullanıcılarının satın alma sonrasında marka farkındalığı ve son olarak sosyal medya kullanıcılarının satın alma sonrası tüketici davranışları bulunmaktadır.

\section{Şekil 2. Araştırmanın Modeli}

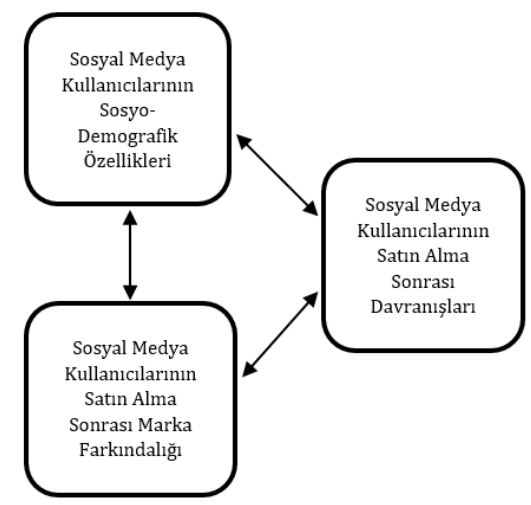

Şekil 2'de yer alan araştırma modeline göre araștırmada test edilecek hipotezler şu şekilde ifade edilebilir:

$\mathrm{H}_{1}$ : Satın alma sonrası marka farkındalığı açısından sosyal medya kullanıcılarının cinsiyetleri arasında istatistiksel olarak anlamlı bir fark bulunmaktadır.

$\mathrm{H}_{2}$ : Satın alma sonrası marka farkındalığı açısından sosyal medya kullanıcılarının yaşları arasında istatistiksel olarak anlamlı bir fark bulunmaktadır.

$\mathrm{H}_{3}$ : Satın alma sonrası marka farkındalığı açısından sosyal medya kullanıcılarının medeni durumları arasinda istatistiksel olarak anlamlı bir fark bulunmaktadır.

$\mathrm{H}_{4}$ : Satın alma sonrası marka farkındalığı açısından sosyal medya kullanıcılarının eğitim durumları arasinda istatistiksel olarak anlaml bir fark bulunmaktadır.

H5: Satın alma sonrası marka farkındalığı açısından sosyal medya kullanıcılarının gelir durumları arasinda istatistiksel olarak anlamlı bir fark bulunmaktadır.
H6: Satın alma sonrası tüketici davranışları açısından sosyal medya kullanıcılarının cinsiyetleri arasında istatistiksel olarak anlamlı bir fark bulunmaktadır.

$\mathrm{H}_{7}$ : Satın alma sonrası tüketici davranışları açısından sosyal medya kullanıcılarının yaşları arasında istatistiksel olarak anlamlı bir fark bulunmaktadır.

H8: Satın alma sonrası tüketici davranışları açısından sosyal medya kullanıcılarının medeni durumları arasında istatistiksel olarak anlamlı bir fark bulunmaktadir.

H9: Satın alma sonrası tüketici davranıșları açısından sosyal medya kullanıcılarının eğitim durumları arasında istatistiksel olarak anlamlı bir fark bulunmaktadır.

$\mathrm{H}_{10}$ : Satın alma sonrası tüketici davranışları açısından sosyal medya kullanıcılarının gelir durumları arasında istatistiksel olarak anlaml bir fark bulunmaktadır.

$\mathrm{H}_{11}$ : Satın alma sonrası marka farkındalığı ile satın alma sonrası sosyal medya kullanıcılarının davranışları arasında istatistiksel olarak anlamlı bir ilişki bulunmaktadır.

\section{6 | ARAŞTIRMANIN BULGULARI}

$\mathrm{Bu}$ kısımda; araştırmada kullanılan ölçeklerin güvenilirlik analizlerine, ölçek puanlarının normallik analizine, tanımlayıcı bilgilere, fark analizlerine ve son olarak da korelasyon analizine yer verilmiştir.

\section{1 | Araştırmada Kullanılan Ölçeklerin Güvenilirlik Analizleri}

Güvenilirlik analizi için kullanılan Cronbach's Alpha değerinin bulunabileceği aralıklar ve buna bağlı olarak da ölçeğin güvenilirlik durumu aşağıda verilmiştir (Büyüköztürk, 2002, s. 78):

- 0,00 $\leq \alpha<0,40$ ise ölçek güvenilir değildir.

- 0,40 $\leq \alpha<0,60$ ise ölçek düşük güvenilirliktedir.

- 0,60 $\leq \alpha<0,80$ ise ölçek oldukça güvenilirdir.

$-0,80 \leq \alpha<1,00$ ise ölçek yüksek derecede güvenilir bir ölçektir.

14 değişkenden oluşan satın alma sonrası marka farkındalığı ölçeğinin güvenilirlik analizi sonucu ulaşılan Cronbach's Alpha değeri 0,895; 9 değişkenden oluşan satın alma sonrası sosyal medya kullanıcı davranışları ölçeği güvenilirlik analizi sonucu ulaşılan Cronbach's Alpha değeri ise 0,882 olarak belirlenmiştir. Bu değerler her iki ölçeğin de yüksek derecede güvenilir olduğunu göstermektedirler. 


\section{2 | Ölçek Puanlarının Normallik Analizi}

Çalışmada kullanılacak analiz yöntemlerinin belirlenmesi amacıyla, çalışmada kullanılan ölçeklere Kolmogorov-Smirnov ve Shapiro-Wilk testleri uygulanmıştır. Testler sonucu ölçek puanlarının normal dağılıp dağılmadığı anlaşılacak, analiz yöntemleri de ona göre tercih edilecektir.

\section{Tablo 1. Normallik Testi}

\begin{tabular}{|c|c|c|c|c|c|}
\hline & SD & \multicolumn{2}{|c|}{$\begin{array}{c}\text { Kolmogorov- } \\
\text { Smirnova }\end{array}$} & \multicolumn{2}{|c|}{ Shapiro-Wilk } \\
\cline { 3 - 6 } & İstatistik & $\mathrm{p}$ & İstatistik & $\mathrm{p}$ \\
\hline $\begin{array}{c}\text { Satın Alma } \\
\text { Sonrası Marka } \\
\text { Farkındalığı }\end{array}$ & 400 & 0,147 & 0,000 & 0,868 & 0,000 \\
\hline $\begin{array}{c}\text { Satın Alma } \\
\text { Sonrası Sosyal } \\
\text { Medya Kullanıcı } \\
\text { Davranışları }\end{array}$ & 400 & 0,058 & 0,003 & 0,973 & 0,000 \\
\hline
\end{tabular}

a. Lilliefors Significance Correction

Tablo 1'deki analiz sonuçları anlamlılık değeri $\mathrm{p}<0,05$ 'den olduğundan her iki ölçeğin de normal dağılım göstermediği sonucuna ulaşılmaktadır. Buna göre fark analizleri için Mann-Whitney U ve Kruskal Wallis testleri, korelasyon için ise Spearman analizi kullanılacaktır.

\section{3 | Tanımlayıcı Bilgiler}

Tablo 2'de sosyal medya kullanıcılarının sosyodemografik özelliklerine (cinsiyet, yaş, medeni durum, eğitim durumu ve gelir durumu) ait bilgiler yer almaktadır.

\section{Tablo 2. Sosyal Medya Kullanıcılarına Ait Bilgiler}

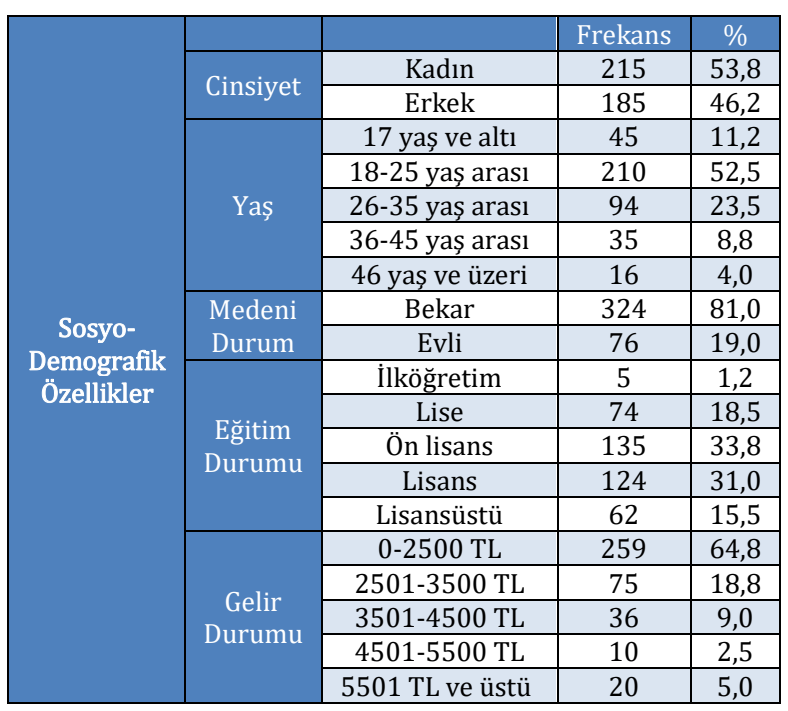

Tablo 3'te ise sosyal medya kullanıcılarının akıllı telefon ve sosyal medya kullanma davranışlarına ait bilgiler görülmektedir.

Tablo 3. Akıllı Telefon ve Sosyal Medya Kullanma Davranışlarına Ait Bilgiler

\begin{tabular}{|c|c|c|c|c|}
\hline & & & Frekans & $\%$ \\
\hline \multirow{7}{*}{$\begin{array}{c}\text { Akıllı } \\
\text { Telefon } \\
\text { Kullanma } \\
\text { Davranışları }\end{array}$} & \multirow{4}{*}{$\begin{array}{l}\text { Kullanılan } \\
\text { Akıllı } \\
\text { Telefon } \\
\text { Markası } \\
\end{array}$} & Apple-IPhone & 172 & 43,0 \\
\hline & & Samsung & 129 & 32,2 \\
\hline & & Huawei & 43 & 10,8 \\
\hline & & Diğer & 56 & 14,0 \\
\hline & \multirow{3}{*}{\begin{tabular}{|c} 
Akıllı \\
Telefon \\
Değiștirme \\
Sıklığı \\
\end{tabular}} & 1 Yıldan az & 128 & 32,0 \\
\hline & & 1-3 Yll Arası & 199 & 49,8 \\
\hline & & 3 Yıldan fazla & 73 & 18,2 \\
\hline \multirow{18}{*}{$\begin{array}{c}\text { Sosyal } \\
\text { Medya } \\
\text { Kullanma } \\
\text { Davranışları }\end{array}$} & \multirow{6}{*}{$\begin{array}{l}\text { En Çok } \\
\text { Kullanılan } \\
\text { Sosyal } \\
\text { Medya Ağı }\end{array}$} & Instagram & 278 & 69,5 \\
\hline & & & & \\
\hline & & YouTube & 66 & 16,5 \\
\hline & & Twitter & 23 & 5,8 \\
\hline & & Facebook & 28 & 7,0 \\
\hline & & Diğer & 5 & 1,2 \\
\hline & \multirow{4}{*}{$\begin{array}{l}\text { Sosyal } \\
\text { Medyada } \\
\text { Günde } \\
\text { Harcanan } \\
\text { Zaman }\end{array}$} & 1 Saatten az & 59 & 14,8 \\
\hline & & 1-2 Saat & 149 & 37,2 \\
\hline & & 3-4 Saat & 141 & 35,2 \\
\hline & & 5 Saat ve üzeri & 51 & 12,8 \\
\hline & \multirow{8}{*}{$\begin{array}{c}\text { En Çok } \\
\text { Hangi } \\
\text { Amaçla } \\
\text { Sosyal } \\
\text { Medya } \\
\text { Kullanıldığı }\end{array}$} & $\begin{array}{c}\text { Ürünler/hizmetler } \\
\text { /markalar } \\
\text { hakkında bilgi } \\
\text { edinmek/takip } \\
\text { etmek } \\
\end{array}$ & 54 & 13,5 \\
\hline & & $\begin{array}{c}\text { Arkadaş } \\
\text { bulmak/takip } \\
\text { etmek } \\
\end{array}$ & 30 & 7,5 \\
\hline & & $\begin{array}{c}\text { Güncel olayları } \\
\text { takip etmek }\end{array}$ & 205 & 51,2 \\
\hline & & $\begin{array}{c}\text { İnsanların } \\
\text { yorum/paylaşımlar } \\
\text { ından faydalanmak }\end{array}$ & 21 & 5,2 \\
\hline & & $\begin{array}{c}\begin{array}{l}\text { Ünlüleri takip } \\
\text { etmek }\end{array} \\
\end{array}$ & 3 & 0,8 \\
\hline & & Oyun oynamak & 8 & 2,0 \\
\hline & & $\begin{array}{l}\text { Müzik dinlemek - } \\
\text { video izlemek }\end{array}$ & 64 & 16,0 \\
\hline & & Diğer & 15 & 3,8 \\
\hline
\end{tabular}

6.4 | Satın Alma Sonrası Marka Farkındalı̆ğ Açısından Sosyal Medya Kullanıcılarının Sosyo-Demografik Özelliklerinin Karşılaştırılması

Araştırmanın bu kısmında satın alma sonrası marka farkındalığı açısından sosyal medya kullanıcılarının sosyo-demografik özelliklerinin (cinsiyet, yaş, medeni durum, eğitim durumu ve gelir durumu) farklılık gösterip göstermediği incelenmiştir. 
Tablo 4. Satın Alma Sonrası Marka Farkındalı̆̆ı Açısından Sosyal Medya Kullanıcılarının Cinsiyetlerinin Karşılaştırılması

\begin{tabular}{|c|c|c|c|c|}
\hline \multicolumn{5}{|c|}{ Satın Alma Sonrası Marka Farkındalığ Ölçeği Ortalaması } \\
\hline Cinsiyet & N & $\begin{array}{c}\text { Sira } \\
\text { Ortalaması }\end{array}$ & $\begin{array}{c}\text { Mann- Whitney } \\
\text { U }\end{array}$ & 17222,500 \\
\hline Kadın & 215 & 188,1 & Wilcoxon W & 40442,500 \\
\hline Erkek & 185 & 214,91 & Z & $-2,314$ \\
\hline Toplam & $\mathbf{4 0 0}$ & & p & 0,021 \\
\hline
\end{tabular}

Tablo 4'te görülen Mann-Whitney U testi sonuçlarına göre sosyal medya kullanıcılarının cinsiyetlerine göre satın alma sonrası marka farkındalığı incelendiğinde, anlamlılık seviyesi $0,021(\mathrm{p}<0,05)$ olduğundan $\mathrm{H}_{1}$ hipotezi kabul edilmektedir ve istatistiksel olarak anlamlı bir fark olduğu sonucuna ulaşılmaktadır. Sosyal medya kullanıcılarının cinsiyetlerine göre sıra ortalamalarına bakıldığında, erkeklerin marka farkındalığı algısının kadınlara göre daha yüksek olduğu anlaşılmaktadır.

Tablo 5. Satın Alma Sonrası Marka Farkındalığı Açısından Sosyal Medya Kullanıcılarının Yaşlarının Karşılaştırılması

\begin{tabular}{|c|c|c|c|c|}
\hline Yaş & $\mathrm{N}$ & $\begin{array}{c}\text { Sira } \\
\text { Ortalaması }\end{array}$ & \multicolumn{2}{|c|}{ Kruskal Wallis Test } \\
\hline 17 yaş ve altı & 45 & 181,73 & \multirow{2}{*}{ Chi-Square } & \multirow{2}{*}{11,657} \\
\hline $18-25$ arası & 210 & 193,37 & & \\
\hline $26-35$ arası & 94 & 232,12 & \multirow{2}{*}{$\mathrm{df}$} & \multirow{2}{*}{4} \\
\hline 36-45 arası & 35 & 203,76 & & \\
\hline 46 ve üzeri & 16 & 154,00 & \multirow{2}{*}{ p } & \multirow{2}{*}{0,020} \\
\hline Toplam & 400 & & & \\
\hline
\end{tabular}

Tablo 5'te görülen Kruskal Wallis testi sonuçlarına göre sosyal medya kullanıcılarının yaşlarına göre satın alma sonrası marka farkındalığı incelendiğinde, anlamlılık seviyesi $0,020(p<0,05)$ olduğundan $\mathrm{H}_{2}$ hipotezi kabul edilmektedir ve istatistiksel olarak anlamlı bir fark olduğu sonucuna ulaşılmaktadır. Yaş dağılımındaki sıra ortalamalarına bakıldığında ise 2635 yaş aralığında yer alan sosyal medya kullanıcılarının diğerlerine oranla daha yüksek marka farkındalığı algısına sahip oldukları anlaşılmaktadır.

Tablo 6. Satın Alma Sonrası Marka Farkındalığı Açısından Sosyal Medya Kullanıclarının Medeni Durumlarının Karşılaştırılması

\begin{tabular}{|c|c|c|c|c|}
\hline \multicolumn{5}{|c|}{ Satın Alma Sonrası Marka Farkındalığı Ölçeği Ortalaması } \\
\hline $\begin{array}{c}\text { Medeni } \\
\text { Durum }\end{array}$ & $\mathrm{N}$ & $\begin{array}{c}\text { Sıra } \\
\text { Ortalaması }\end{array}$ & $\begin{array}{c}\text { Mann- } \\
\text { Whitney U }\end{array}$ & 11017,500 \\
\hline Bekar & 324 & 204,50 & Wilcoxon W & 13943,500 \\
\hline Evli & 76 & 183,47 & $\mathrm{Z}$ & $-1,428$ \\
\hline Toplam & $\mathbf{4 0 0}$ & & $\mathrm{p}$ & 0,153 \\
\hline
\end{tabular}

Tablo 6'da görülen Mann-Whitney U testi sonuçlarına göre sosyal medya kullanıcılarının medeni durumlarına göre satın alma sonrası marka farkındalığı incelendiğinde, anlamlılık seviyesi 0,153 ( $p>0,05)$ olduğundan $\mathrm{H}_{3}$ hipotezi reddedilmektedir ve istatistiksel olarak anlamlı bir fark olmadığ sonucuna ulaşılmaktadır.

Tablo 7. Satın Alma Sonrası Marka Farkındalığı Açısından Sosyal Medya Kullanıcılarının Eğitim Durumlarının Karşılaştırılması

\begin{tabular}{|c|c|c|c|c|}
\hline \multicolumn{5}{|c|}{ Satın Alma Sonrası Marka Farkındalığı Ölçeği Ortalaması } \\
\hline $\begin{array}{l}\text { Eğitim } \\
\text { Durumu }\end{array}$ & $\mathrm{N}$ & $\begin{array}{c}\text { Sira } \\
\text { Ortalaması }\end{array}$ & \multicolumn{2}{|c|}{ Kruskal Wallis Test } \\
\hline İlköğretim & 5 & 204,90 & \multirow{2}{*}{ Chi-Square } & \multirow{2}{*}{4,894} \\
\hline Lise & 74 & 184,61 & & \\
\hline Ön lisans & 135 & 190,76 & \multirow{2}{*}{ df } & \multirow{2}{*}{4} \\
\hline Lisans & 124 & 215,34 & & \\
\hline Lisansüstü & 62 & 210,64 & \multirow[b]{2}{*}{$\mathrm{p}$} & \multirow{2}{*}{0,298} \\
\hline Toplam & 400 & & & \\
\hline
\end{tabular}

Tablo 7'de görülen Kruskal Wallis testi sonuçlarına göre sosyal medya kullanıcılarının eğitim durumlarına göre satın alma sonrası marka farkındalığı incelendiğinde, anlamlılık seviyesi 0,298 ( $p>0,05)$ olduğundan $\mathrm{H}_{4}$ hipotezi reddedilmektedir ve istatistiksel olarak anlamlı bir fark olmadığ sonucuna ulaşılmaktadır.

Tablo 8. Satın Alma Sonrası Marka Farkındalığı Açısından Sosyal Medya Kullanıcılarının Gelir Durumlarının Karşılaştırılması

\begin{tabular}{|c|c|c|c|c|}
\hline \multicolumn{5}{|c|}{ Satın Alma Sonrası Marka Farkındalığı Ölçeğı Ortalaması } \\
\hline Gelir Durumu & $\mathrm{N}$ & $\begin{array}{c}\text { Sira } \\
\text { Ortalaması }\end{array}$ & \multicolumn{2}{|c|}{$\begin{array}{c}\text { Kruskal Wallis } \\
\text { Test }\end{array}$} \\
\hline $0-2500$ TL arası & 259 & 191,08 & \multirow{2}{*}{$\begin{array}{c}\text { Chi- } \\
\text { Square }\end{array}$} & \multirow{2}{*}{5,555} \\
\hline 2501-3500 TL arası & 75 & 214,78 & & \\
\hline 3501-4500 TL arası & 36 & 217,07 & \multirow{2}{*}{$\mathrm{df}$} & \multirow{2}{*}{4} \\
\hline 4501-5500 TL arası & 10 & 206,1 & & \\
\hline 5501 TL ve üstü & 20 & 236,3 & \multirow[b]{2}{*}{$\mathrm{p}$} & \multirow{2}{*}{0,235} \\
\hline Toplam & 400 & & & \\
\hline
\end{tabular}

Tablo 8'de görülen Kruskal Wallis testi sonuçlarına göre sosyal medya kullanıcılarının gelir durumlarına göre satın alma sonrası marka farkındalığı incelendiğinde, anlamlılık seviyesi 0,235 ( $p>0,05)$ olduğundan $\mathrm{H}_{5}$ hipotezi reddedilmektedir ve istatistiksel olarak anlamlı bir fark olmadığı sonucuna ulaşılmaktadır.

6.5 | Satın Alma Sonrası Tüketici Davranışları Açısından Sosyal Medya Kullanıcılarının SosyoDemografik Özelliklerinin Karşılaştırılması

Araştırmanın bu kısmında satın alma sonrası tüketici davranışları açısından sosyal medya kullanıcılarının sosyo-demografik özelliklerinin (cinsiyet, yaş, medeni durum, eğitim durumu ve gelir durumu) farklılık gösterip göstermediği incelenmiştir. 
Tablo 9. Satın Alma Sonrası Sosyal Medya Kullanıcı Davranışları Açısından Cinsiyetlerin Karşılaştırılması

\begin{tabular}{|c|c|c|c|c|}
\hline \multicolumn{5}{|c|}{ Satın Alma Sonrası Sosyal Medya Kullanıcı Davranışları Ölçeği } \\
Ortalaması
\end{tabular}

Tablo 9'da görülen Mann-Whitney U testi sonuçlarına göre sosyal medya kullanıcılarının cinsiyetlerine göre satın alma sonrası sosyal medya kullanıcı davranışları incelendiğinde, anlamlıllk seviyesi $0,940(p>0,05)$ olduğundan $\mathrm{H}_{6}$ hipotezi reddedilmektedir ve istatistiksel olarak anlamlı bir fark olmadı ğı sonucuna ulaşılmaktadır.

Tablo 10. Satın Alma Sonrası Sosyal Medya Kullanıcı Davranışları Açısından Yaşların Karşılaştırılması

\begin{tabular}{|c|c|c|c|c|}
\hline \multicolumn{4}{|c|}{ Satın Alma Sonrası Sosyal Medya Kullanıcı Davranışları } \\
Ölçeği Ortalaması
\end{tabular}

Tablo 10'da görülen Kruskal Wallis testi sonuçlarına göre sosyal medya kullanıcılarının yaşlarına göre satın alma sonrası sosyal medya kullanıcı davranıșları incelendiğinde, anlamlılık seviyesi $0,000(p<0,05)$ olduğundan $\mathrm{H}_{7}$ hipotezi kabul edilmektedir ve istatistiksel olarak anlamlı bir fark olduğu sonucuna ulaşılmaktadır. Yaş dağılımındaki sıra ortalamalarına bakıldığında 26-35 yaş aralı̆̆ında yer alanların diğerlerine oranla daha fazla satın alma sonrası davranış sergiledikleri anlaşılmaktadır.

Tablo 11. Satın Alma Sonrası Sosyal Medya Kullanıcı Davranışları Açısından Medeni Durumların Karşılaştırılması

\begin{tabular}{|c|c|c|c|c|}
\hline \multicolumn{5}{|c|}{ Satın Alma Sonrası Sosyal Medya Kullanıcı Davranışları } \\
Ölçeği Ortalaması \\
\hline $\begin{array}{c}\text { Medeni } \\
\text { Durum }\end{array}$ & N & $\begin{array}{c}\text { Sıra } \\
\text { Ortalaması }\end{array}$ & $\begin{array}{c}\text { Mann- } \\
\text { Whitney U }\end{array}$ & 10000,500 \\
\hline Bekar & 324 & 193,37 & Wilcoxon W & 62650,500 \\
\hline Evli & 76 & 230,91 & Z & $-2,550$ \\
\hline Toplam & 400 & & p & 0,011 \\
\hline
\end{tabular}

Tablo 11'de görülen Mann-Whitney $U$ testi sonuçlarına göre sosyal medya kullanıcılarının medeni durumlarına göre satın alma sonrası sosyal medya kullanıcı davranışları incelendiğinde, anlamlılık seviyesi $0,011(\mathrm{p}<0,05)$ olduğundan $\mathrm{H}_{8}$ hipotezi kabul edilmektedir ve istatistiksel olarak anlamlı bir fark olduğu sonucuna ulassılmaktadır. Medeni duruma göre sıra ortalamalarına bakıldığında evli olanların daha fazla satın alma sonrası davranıș sergiledikleri anlaşılmaktadır.

Tablo 12. Satın Alma Sonrası Sosyal Medya Kullanıcı Davranışları Açısından Eğitim Durumlarının Karşılaştırılması

\begin{tabular}{|c|c|c|c|c|}
\hline \multicolumn{5}{|c|}{$\begin{array}{c}\text { Satın Alma Sonrası Sosyal Medya Kullanıcı Davranışları Ölçeği } \\
\text { Ortalaması }\end{array}$} \\
\hline Eğitim Durumu & $\mathrm{N}$ & $\begin{array}{c}\text { Sira } \\
\text { Ortalaması }\end{array}$ & \multicolumn{2}{|c|}{ Kruskal Wallis Test } \\
\hline İlköğretim & 5 & 196,80 & \multirow{2}{*}{$\begin{array}{c}\text { Chi- } \\
\text { Square }\end{array}$} & \multirow{2}{*}{14,454} \\
\hline Lise & 74 & 173,39 & & \\
\hline Ön lisans & 135 & 185,53 & \multirow{2}{*}{$\mathrm{df}$} & \multirow{2}{*}{4} \\
\hline Lisans & 124 & 214,88 & & \\
\hline Lisansüstü & 62 & 236,99 & \multirow{2}{*}{$\mathrm{p}$} & \multirow{2}{*}{0,006} \\
\hline Toplam & 400 & & & \\
\hline
\end{tabular}

Tablo 12'de görülen Kruskal Wallis testi sonuçlarına göre sosyal medya kullanıcılarının eğitim durumlarına göre satın alma sonrası sosyal medya kullanıcı davranışları incelendiğinde, anlamlılık seviyesi 0,006 $(\mathrm{p}<0,05)$ olduğundan $\mathrm{H}_{9}$ hipotezi kabul edilmektedir ve istatistiksel olarak anlamlı bir fark olduğu sonucuna ulaşılmaktadır. Eğitim durumuna göre sıra ortalamalarına bakıldığında lisansüstü mezunu olanların daha fazla satın alma sonrası davranış sergiledikleri görülmektedir.

Tablo 13. Satın Alma Sonrası Sosyal Medya Kullanıcı Davranışları Açısından Katılımcıların Gelir Durumun Karşılaştırılması

\begin{tabular}{|c|c|c|c|c|}
\hline \multicolumn{5}{|c|}{$\begin{array}{c}\text { Satın Alma Sonrası Sosyal Medya Kullanıcı Davranışları Ölçeği } \\
\text { Ortalaması }\end{array}$} \\
\hline Gelir Durumu & $\mathrm{N}$ & $\begin{array}{c}\text { Sira } \\
\text { Ortalamasi }\end{array}$ & \multicolumn{2}{|c|}{$\begin{array}{l}\text { Kruskal Wallis } \\
\text { Test }\end{array}$} \\
\hline $0-2500$ TL arası & 259 & 191,11 & \multirow{2}{*}{$\begin{array}{l}\text { Chi- } \\
\text { Square }\end{array}$} & \multirow{2}{*}{4,963} \\
\hline 2501-3500 TL arası & 75 & 218,92 & & \\
\hline 3501-4500 TL arası & 36 & 213,53 & \multirow{2}{*}{$\mathrm{df}$} & \multirow{2}{*}{4} \\
\hline 4501-5500 TL arası & 10 & 213,60 & & \\
\hline 5501 TL ve üstü & 20 & 223,00 & \multirow[b]{2}{*}{$\mathrm{p}$} & \multirow{2}{*}{0,291} \\
\hline Toplam & 400 & & & \\
\hline
\end{tabular}

Tablo 13'te görülen Kruskal Wallis testi sonuçlarına göre sosyal medya kullanıcılarının gelir durumlarına göre satın alma sonrası sosyal medya kullanıcı davranıșları incelendiğinde, anlamlılık seviyesi 0,291 ( $p>0,05)$ olduğundan $\mathrm{H}_{10}$ hipotezi reddedilmektedir ve istatistiksel olarak anlamlı bir fark olmadığı sonucuna ulaşılmaktadır.

6.6 | Satın Alma Sonrası Marka Farkındalığı ile Sosyal Medya Kullanıcı Davranışları Arasındaki İlişki

$\mathrm{Bu}$ kısımda satın alma sonrasında marka farkındalığı ile satın alma sonrası sosyal medya kullanıcılarının davranışları arasında anlamlı bir ilișki olup olmadığını test etmeye yönelik korelasyon analizine yer verilmiştir. 
Tablo 14. Satın Alma Sonrası Marka Farkındalığı ile Satın Alma Sonrası Sosyal Medya Kullanicı Davranışları Arasındaki İlişki

\begin{tabular}{|c|c|c|c|}
\hline & & $\begin{array}{c}\text { Marka } \\
\text { Farkındalı̆̆ı }\end{array}$ & $\begin{array}{l}\text { Satin Alma Sonrası } \\
\text { Sosyal Medya } \\
\text { Kullanicı Davranıș }\end{array}$ \\
\hline \multirow{3}{*}{$\begin{array}{c}\text { Marka } \\
\text { Farkındalığı }\end{array}$} & Korelasyon & 1,000 & $0,198^{* *}$ \\
\hline & $\mathrm{p}$ & & 0,000 \\
\hline & $\mathrm{N}$ & 0400 & 400 \\
\hline \multirow{3}{*}{$\begin{array}{c}\text { Satın Alma } \\
\text { Sonrası Sosyal } \\
\text { Medya } \\
\text { Kullanicı } \\
\text { Davranıșı } \\
\end{array}$} & Korelasyon & $0,198^{* *}$ & 1,000 \\
\hline & $\mathrm{p}$ & 0,000 & \\
\hline & $\mathrm{N}$ & 400 & 400 \\
\hline
\end{tabular}

**. Correlation is significant at the 0.01 level (2tailed).

Tablo 14'te görüldüğü üzere satın alma sonrası marka farkındalığı ile satın alma sonrası sosyal medya kullanıcı davranıșları arasında istatistiksel olarak anlamlı bir ilişki bulunmaktadır. Anlamlılık seviyesi $0,000(\mathrm{p}<0,05)$ olduğundan, $\mathrm{H}_{11}$ hipotezi kabul edilmektedir ve istatistiksel olarak anlamlı bir ilişki olduğu sonucuna ulaşılmaktadır. Aralarında pozitif yönlü 0,198'lik zayıf bir ilişki bulunmaktadır. Sosyal medya kullanıcılarının satın alma sonrası marka farkındalığı arttıkça veya satın alma sonrası sosyal medya kullanıcı davranışları fazlalaştıkça bir diğeri de artmakta ya da fazlalaşmaktadır.

\section{7 | SONUÇ VE ÖNERILER}

Sosyal medya, gün geçtikçe hayatın her alanına yayılarak günlük yaşamın vazgeçilmez bir parçası olmaya devam etmektedir. Sosyal medya kullanım sıklığının artması ile markaların rakiplerine göre bir adım önde olmak için sosyal medyada yoğun bir şekilde yer almayı tercih ettiklerini söylemek mümkündür. $\mathrm{Bu}$ durum aynı zamanda tüketici nezdinde marka farkındalıklarının da artmasına neden olabilmektedir.

Marka farkındalığı oluşturmak için sosyal medyada yapılan paylaşımların marka ile uyumlu, markaya özgü ya da taklit edilemeyen, tüketicinin istek ve ihtiyaçlarına hitap eden, rakip markalardan farklı, orijinal ve akılda kalıcı içeriklere sahip olması gerektiğini ifade etmek mümkündür.

Bu noktadan hareketle yapılan çalışmada temel amaç; sosyal medya kullanıcılarının satın alma sonrası marka farkındalığı ve tüketici davranışları arasındaki ilişkinin incelenmesidir. Bunun için 400 akıllı telefon kullanan sosyal medya kullanıcısı ile anket çalışması gerçekleştirilmiştir.

Araştırmaya dahil olan sosyal medya kullanıcılarının en çok kullandıkları akıllı telefon markalarının AppleIPhone (172 kişi, \%43,0) ve Samsung (129 kişi, \%32,2) olduğu görülmüștür. Akıllı telefon değiştirme sıklığının en fazla 1-3 yıl arasına (199 kişi, \%49,8) yoğunlaştığı tespit edilmiştir.
Sosyal medya kullanıcılarının yarısından fazlasının sosyal medyada en çok kullandığı sosyal ağın Instagram (278 kişi, \%69,5), ikinci olarak YouTube (66 kişi, \%16,5) ve üçüncü olarak ise Facebook (28 kişi, \%7,0) olduğu ortaya çıkmıștır. We are social ve Hootsuit tarafindan "Digital in 2018 in Western Asia" ismiyle hazırlanan sosyal medya istatistiklerine göre ise Türkiye'de kullanılan en aktif sosyal ağların ilk üçü, YouTube, Facebook ve Instagram olarak sıralanmaktadır (Salih, 2018). Bu sıralamanın, çalışmada elde edilen ilk üç sosyal ağ ile benzerlik gösterdiğini ifade etmek mümkündür.

Sosyal medyada günde harcanan zaman açısından en fazla sayı ve orana sahip olan zaman aralı̆ 1 1-2 saat arası $(149$ kişi, \%37,2) olarak belirlenmiştir. Araştırmaya katılanların yarısından fazlasının, sosyal medyayı en çok kullanma amacının güncel olayları takip etmek (205 kişi, \%51,2) olduğu belirlenmiştir. $\mathrm{Bu}$ sonuçlar, Duygun (2018, s. 1371) tarafından yapılan çalışma sonucu ile de benzerlik göstermektedir.

Çalışmada; sosyal medya kullanıcılarının cinsiyetlerine göre satın alma sonrası marka farkındalı̆̆ anlamlı bir fark olduğu sonucuna ulașılmıștır. Sosyal medya kullanıcılarının cinsiyetlerine göre sıra ortalamalarına bakıldığında, erkeklerin marka farkındalığı algısının kadınlara göre daha yüksek olduğu anlaşılmıştır.

Sosyal medya kullanıcılarının yaşlarına göre satın alma sonrası marka farkındalığı incelendiğinde, istatistiksel olarak anlamlı bir fark olduğu sonucuna ulaşılmıştır. Yaş dağılımındaki sıra ortalamalarına bakıldığında ise 26-35 yaş aralığında yer alan sosyal medya kullanıcılarının diğerlerine oranla daha yüksek marka farkındalığı algısına sahip oldukları ortaya çıkmıştır.

Sosyal medya kullanıcılarının medeni durumlarına, eğitim durumlarına ve gelir durumlarına göre satın alma sonrası marka farkındalı̆̆ incelendiğinde, istatistiksel olarak anlamlı bir fark olmadığı sonucuna varılmıştır.

Sosyal medya kullanıcılarının cinsiyetlerine, gelir durumlarına göre satın alma sonrası sosyal medya kullanıcı davranışları incelendiğinde, istatistiksel olarak anlamlı bir fark olmadığı sonucuna varılmıştır. İşlek'in (2012) çalışmasında da, cinsiyet açısından benzer bir sonuca ulaşılırken (İşlek, 2012, s. 135), gelir durumu açısından farklı bir sonuca ulaşılmış, gelir durumuna göre sosyal medyada satın alma sonrası tüketici davranışında kısmen fark olduğu (İşlek, 2012, s. 139) saptanmıştır.

Sosyal medya kullanıcılarının yaşlarına göre satın alma sonrası sosyal medya kullanıcı davranışları incelendiğinde, istatistiksel olarak anlamlı bir fark olduğu sonucuna ulaşılmıştır. Yaş dağılımındaki sıra 
ortalamalarına bakıldığında 26-35 yaș aralı̆̆ında yer alanların diğerlerine oranla daha fazla satın alma sonrası davranış sergiledikleri anlaşılmıştır. İşlek'in (2012) çalışmasında ise yaş açısından tersi bir sonuca ulaşılmıştır. Yaş gruplarına göre sosyal medyada satın alma sonrası tüketici davranıșında fark olmadığı ortaya konmuştur (İşlek, 2012, s. 137).

Sosyal medya kullanıcılarının medeni durumlarına göre satın alma sonrası sosyal medya kullanıcı davranışları incelendiğinde, istatistiksel olarak anlamlı bir fark olduğu sonucuna varılmıștır. Medeni duruma göre sıra ortalamalarına bakıldığında evli olanların daha fazla satın alma sonrası davranış sergiledikleri belirlenmiștir.

Sosyal medya kullanıcılarının eğitim durumlarına göre satın alma sonrası sosyal medya kullanıcı davranışları incelendiğinde, istatistiksel olarak anlamlı bir fark olduğu sonucuna ulaşılmıştır. Eğitim durumuna göre sıra ortalamalarına bakıldığında lisansüstü mezunu olanların daha fazla satın alma sonrası davranış sergiledikleri ortaya çıkmıştır. İşlek'in (2012) çalışmasında ise eğitim durumları açısından tersi bir sonuca ulaşılmıştır. Eğitim durumlarına göre sosyal medyada satın alma sonrası tüketici davranışında fark olmadığı ortaya çıkmıştır (İşlek, 2012, s. 138).

Son olarak; satın alma sonrası marka farkındalığı ile satın alma sonrası sosyal medya kullanıcı davranışları arasında istatistiki olarak anlamlı bir ilişki olduğu belirlenmiştir. Aralarında pozitif yönlü 0,198'lik zaylf bir ilişki bulunmuştur. Buna göre sosyal medya kullanıcılarının satın alma sonrası marka farkındalığı arttıkça veya satın alma sonrası sosyal medya kullanıcı davranışları fazlalaştıkça bir diğeri de artmakta ya da fazlalaşmaktadır. Benzer bir sonuç olarak; Aytan ve Telci (2014, s. 1) markaların sosyal medya kullanımının tüketici davranıșları üzerinde etkili olduğunu ortaya koymuşlardır. Shojaee ve bin Azman (2013, s. 72) yaptıkları çalışmada daha geniş kapsamlı bir ilişki ortaya koyarak, benzer bir sonuca ulaşmışlar; müşteri etkileşimi, marka yayılımı ve elektronik ağızdan ağıza iletişimin sosyal medya bağlamında marka farkındalığ korelasyona sahip olduğunu ve en etkili faktörün müşteri etkileşimi olduğunu saptamışlardır. Araştırmanın sonucunu destekler nitelikteki bir diğer çalışma Bilgin (2018, s. 128) tarafinda ortaya konmuş ve sosyal medyaki pazarlama aktivitelerinin, en belirgin etkisinin marka farkındalığı üzerinde olduğu belirlenmiștir. Son olarak; Momany ve Alshboul (2016, s. 33) sosyal medyadaki sosyal yardım çabaları ile marka farkındalığı ve çevrimiçi satışlar arasında güçlü korelasyonlar olduğunu tespit etmişlerdir.

Sosyal medya, işletme ve tüketici arasında bir iletişim bağı oluşturmaktadır. Geleneksel araçlardan farklı olarak anlık iletişim ve hızlı geribildirim gibi avantajlar sağlamaktadır. Tüketiciden gelen olumlu veya olumsuz geri bildirimler hızla yanıtlandırılmalı ve soruna çözüm üretilmelidir. Böylelikle markanın tüketici ile kurduğu ilişkiyi kalıcı hale getirmesi mümkündür.

İşletmelerin müşteri hizmetlerini sosyal medyada da sürdürmesinin marka farkındalığı açısından önemli bir unsur olduğunu söylemek mümkündür. Sosyal medyada markaların tüketicileri ile irtibatta olması, ürün ve hizmetleri konusunda olumlu ya da olumsuz düşüncelerini öğrenmeye çalışması, onların istek, öneri ve şikâyetlerine duyarsız kalmayarak geri bildirimde bulunması herhangi bir kriz döneminde olumsuz ve imaj zedeleyici yorumları en aza indirebilmektedir.

Ayrıca bu konularda çalışmak isteyen akademisyen ve araştırmacılara da bazı önerilerde bulunmak mümkün olabilir. Öncelikle araştırma İstanbul dışında başka bir il ya da bölgede tekrarlanıp, elde edilen sonuçlar karşılaştırılabilir. Böylelikle il ya da bölge bazında sosyo-demografik özellikler açısından farklılıkların olup olmadığını tespit etmek mümkün hale gelebilir.

Bir diğer öneri ise sosyal medya kullanıcıları dışında farklı bir tüketici grubu ile araştırma tekrarlanabilir ve sonuçlar karşılaştırılabilir. Böylelikle, sosyal medya kullanıcılarının tüketici davranışları ile diğerlerinin olası farklılıkları ortaya çıkarılabilir ve sosyal medyanın satın alma sonrası tüketici davranışına ne derece etki ettiği ya da etmediği daha net anlaşılabilir.

Son olarak, satın alma sonrası marka farkındalığı ile satın alma sonrası sosyal medya kullanıcı davranışları arasındaki ilişkinin zayıf olduğu düşünüldüğünde, satın alma sonrası marka farkındalığı ve sosyal medya kullanıcılarının davranışları ile birlikte incelenebileceği ya da ikisi arasında aracı etkide bulunabileceği düşünülen farklı değişken ya da değişkenlerle de araştırma tekrarlanabilir. 


\section{KAYNAKÇA}

Aktepe, C. \& Baş, M. (2008). Marka Bilgi Sürecinde Marka Farkındalığı ve Algılanan Kalite (Beklenti) İlişkisi ve GSM Sektörüne Yönelik Bir Analiz. Gazi Üniversitesi Íktisadi ve Ídari Bilimler Dergisi, 10(1): 81-96.

Aktuğlu, I. K. \& Temel, A. (2006). Tüketiciler Markaları Nasıl Tercih Ediyor? (Kamu Sektörü Çalışanlarının Giysi Markalarını Tercihini Etkileyen Faktörlere Yönelik Bir Araştırma). Selçuk Üniversitesi Sosyal Bilimler Enstitüsü Dergisi, (15): 43-59.

Ar, A. A. (2004). Marka ve Marka Stratejileri, Detay Yayıncıllk, İstanbul.

Avcılar, M. Y. (2008). Tüketici Temelli Marka Değerinin Ölçümü. C.Ü. Sosyal Bilimler Enstitüsü Dergisi, 17(1): 11-30.

Ayas, N. (2012). Marka Değeri Algllamalarının Tüketici Satın Alma Davranışı Üzerine Etkisi. Girişimcilik ve Kalkınma Dergisi, 7(1): 163-183.

Aytan, C. \& Telci, E. E. (2014). Markaların Sosyal Medya Kullanımının Tüketici Davranışı Üzerine Etkileri. The Turkish Online Journal of Design, Art and Communication - TOJDAC, 4(4), 1-15.

Bardakçı, H., Özçelik, O. \& Kılıç, S. (2015). Cinsiyet İle Tüketici Davranışları Arasındaki İlişkinin İncelenmesi ve Ampirik Bir Uygulama. Uluslararası Sosyal Araştırmalar Dergisi, 8(40): 620-626.

Barreda, A. A., Bilgihan, A., Nusair, K. \& Okumus, F. (2015). Generating Brand Awareness in Online Social Networks. Computers in Human Behavior, 50, 600609.

Bilgin, Y. (2018). The Effect of Social Media Marketing Activities on Brand Awareness, Brand Image and Brand Loyalty. Business \& Management Studies: An International Journal - BMIJ, 6(1), 128-148

Büyüköztürk, Ș. (2002). Sosyal Bilimler için Veri Analizi El Kitabı Ístatistik, Araştırma Deseni SPSS Uygulamaları ve Yorum. Pegem Akademi Yayıncılık, Ankara.

Cop, R. \& Baş, Y. (2010). Marka Farkındalığı ve Marka İmajı Unsurlarına Karşı Tüketici Algıları Üzerine Bir Araștırma. Sosyal Ekonomik Araştırmalar Dergisi, 10(19): 321-340.

Çetinsöz, B. C. \& Artuğer, S. (2013). Antalya İli'nin Marka Değerinin Ölçülmesine Yönelik Bir Araştırma. Anatolia: Turizm Araştırmaları Dergisi, 24(2): 200210.
Durmaz, Y. (Oruç) Bahar, R. \& Kurtlar, M. (2011). Kişisel Faktörlerin Tüketici Satın Alma Davranışlarına Etkisi Üzerine Bir Araştırma. Akademik Yaklaşımlar Dergisi, 2(1): 114-133.

Duygun, A. (2020). Örneklerle Sosyal Medyada Tüketici Davranışları. Hiperyayın, 564, İstanbul.

Duygun, A. (2018). Sosyal Medya Bağımlılığının Tüketici Satın Alma Karar Sürecine Etkisi. Gümüşhane Üniversitesi İletişim Fakültesi Elektronik Dergisi, 6(2), 1351-1375.

Erciş, A., Yapraklı, Ș. \& Can, P. (2009). Güçlü ve Güçsüz Markalarda Marka Bilgisi, Marka İlişkileri ve Satın Alma Davranışları Arasındaki Farklılıkların İncelenmesi. Marmara Üniversitesi Íktisadi ve Ídari Bilimler Dergisi, 26(1): 157-190.

Hacıŏlu Deniz, M. (2011). Markalı Ürün Tercihlerinin Satın Alma Davranıșları Üzerindeki Etkisi. Sosyal Siyaset Konferansları Dergisi, (61): 243268.

Hollebeek, L. D., Glynn, M. S. \& Brodie, R. J. (2014). Consumer Brand Engagement in Social Media: Conceptualization, Scale Development and Validation. Journal of Interactive Marketing, 28, 149-165.

İşlek, M. S. (2012). Sosyal Medyanın Tüketici Davranışlarına Etkileri: Türkiye'deki Sosyal Medya Kullanıcıları Üzerine Bir Araştırma. Karamanoğlu Mehmet Bey Üniversitesi, Sosyal Bilimler Enstitüsü, ISsletme Ana Bilim Dal, Yayımlanmamış Yüksek Lisans Tezi.

Kaplan, A. M. \& Haenlein, M. (2010). Users of The World, Unite! The Challenges and Opportunities of Social Media. Business Horizons, 53, 59-68.

Kazancl, Ş. \& Başgöze, P. (2015). Sosyal Medya Algısının, Marka Kredibilitesinin ve Marka Prestijinin Satın Alma Eğilimi Üzerine Etkileri. Ankara Üniversitesi SBF Dergisi, 70(2), 435-456.

Momany, M. \& Alshboul, A. (2016). Social Media Marketing: Utilizing Social Media to Advance Brand Awareness and Increase Online Sales. International Journal of Business, Marketing, and Decision Sciences, 9(1), 33-54.

Mucuk, İ. (2001). Pazarlama Illkeleri. Türkmen Kitabevi, İstanbul.

Odabaşı, Y. \& Oyman, M. (2003). Pazarlama İletişimi Yönetimi. 3. Baskı, İstanbul: MediaCat Kitapları.

Odabaşı, Y. (1998). Tüketici Davranışı ve Pazarlama Stratejisi. Anadolu Üniversitesi Yayınları, Eskişehir. 
Pira, A., Kocabaş, F. \& Yeniçeri, M. (2005). Küresel Pazarda Marka Yönetimi ve Halkla Ílişkiler. Dönence Basım ve Yayın Hizmetleri, İstanbul.

Salih, C. (2018). 2018 Türkiye İnternet Kullanım ve Sosyal Medya İstatistikleri, Erişim Adresi: https://dijilopedi.com/2018-turkiye-internetkullanim-ve-sosyal-medya-istatistikleri/, Erişim Tarihi: 10.04.2019.

Shojaee, S. \& bin Azman, A. (2013). An Evaluation of Factors Affecting Brand Awareness in the Context of Social Media in Malaysia. Asian Social Science; 9(17), 72-78.

Toksarl, M., Mürütsoy, M. \& Bayraktar, M. (2014). Tüketici Algılarını Etkileyen Faktörlerde Sosyal Medyanın Rolü: Niğde Üniversitesi İ.İ.B.F. Örneği. Uşak Üniversitesi Sosyal Bilimler Dergisi, 20, 1-28.

Ural, T. \& Perk, H. G. (2012). Tüketici Temelli Marka Değerinin Kişisel Bilgisayar Satın Alma Niyeti Üzerine Etkisi: Antakya'da Bir Çalışma. Anadolu Üniversitesi Sosyal Bilimler Dergisi, 12(3): 11-25. 